Article

\title{
Phenolic Compounds Characterization and Antioxidant Properties of Monocultivar Olive Oils from Northeast Algeria
}

\author{
Soulef Boussahel ${ }^{1,2}\left(\mathbb{D}\right.$, Vita Di Stefano ${ }^{3, *}\left(\mathbb{D}\right.$, Claudia Muscarà $^{4,5}$, Mariateresa Cristani ${ }^{4}$ \\ and Maria Grazia Melilli ${ }^{6, *(\mathbb{D})}$
}

1 Department of Biological Sciences, Faculty of Nature and Life Sciences and Sciences of Earth and Universe, University of Bordj Bou Arreridj, Bordj Bou Arreridj 34030, Algeria; boussahel.soulef@gmail.com

2 Laboratory of Phytotherapy Applied to Chronic Diseases, Department of Biology and Animal Physiology, Faculty of Nature and Life Sciences, University Setif 1, Setif 19000, Algeria

3 Department of Biological, Chemical and Pharmaceutical Sciences and Technologies (STEBICEF) University of Palermo, 90123 Palermo, Italy

4 Department of Chemical, Biological, Pharmaceutical and Environmental Sciences, University of Messina, 98165 Messina, Italy; claudia.muscara@gmail.com (C.M.); mcristani@unime.it (M.C.)

5 Foundation “Prof. Antonio Imbesi”, University of Messina, Piazza Pugliatti 1, 98122 Messina, Italy

6 Institute for Agricultural and Forest Systems in the Mediterranean, National Council of Research, 95128 Catania, Italy

* Correspondence: vita.distefano@unipa.it (V.D.S.); mariagrazia.melilli@cnr.it (M.G.M.); Tel.: +39-091-23891948 (V.D.S.); +39-0956139916 (M.G.M.)

Received: 23 September 2020; Accepted: 21 October 2020; Published: 23 October 2020

\begin{abstract}
In Algeria, the olive tree is one of the main fruit species and plays a very important socioeconomic role. The objective of this study was firstly, to identify and quantify the phenolics of some Algerian olive oils, and secondly, to assess the antioxidant activity of the samples. The olive oils used in this study were derived from Algerian cultivars, including Tefahi, Gelb Elfarroudj, Chemlal, and imported cultivar Manzanilla and Zebboudj. For this purpose, gas chromatography-mass spectrometry (GC-MS) was used to identify olive oil fatty acids profile, while the individual phenolic compounds were assessed by ultra-high-performance liquid chromatography-electrospray ionization-high-resolution mass spectrometry (UHPLC-HESI-MS). To verify the antioxidant capacity, five in vitro free radical assays were used. Questionable values of particular physico-chemical parameters, such as the high value of free acidity and the low concentration of monounsaturated fatty acids in oil from the Zebboudj cultivar, indicate that improvements in olive cultivation and oil production practices are needed. Gelb Elfarroudj, Tefahi, and Manzanilla oils contain quantities of monounsaturated fatty acids in accordance with EU regulations. The oil obtained from the Zebboudj cultivar is not usable for food purposes due to the high value in free acidity and the low concentration of monounsaturated fatty acids. Tefahi and Manzanilla cultivars have given oils with the best antioxidant activity as compared to other studied cultivars; this is attributable to their composition in bioactive phenolic compounds, such as secoiridoids, which play an important role in human health as scavengers of free radicals. The results are interesting for producers and consumers to promote the culture of olive oils derived in particular from the Tefahi cultivar. However, in order to improve the health qualities of this oil, the agronomic techniques essentially linked to the time of harvesting of the olives destined for oil production must be improved.
\end{abstract}

Keywords: Manzanilla; Tefahi; Gelb Elfarroudj cultivar; secoiridoids; radical scavenging; UHPLC-HESI-MS; phenolics 


\section{Introduction}

Olea europaea L., or more commonly olive tree, is largely cultivated for the production of its nutritional and healthy fruits. Extra virgin olive oil (EVOO) is an integral ingredient of the Mediterranean diet and a wide number of analytical techniques were used to identify the chemical composition [1]. These techniques indicated that the fine characteristics, the good health effect, and the biological activity of EVOO are mainly attributed to the presence of the unsaturated fatty acids as major components. They are recognized in olive oils mostly by the presence of the acids: oleic (C18:1), palmitic (C16:0), palmitoleic (C16:1), stearic (C18:0), linoleic (C18:2), and linolenic (C18:3). The high quality of olive oil is also attributed to the presence in its composition of minor components such as phytosterols, carotenoids, tocopherols and hydrophilic phenols. The major phenolic compounds present in olive oil and conferring it the antioxidant activity belong to the class of secoiridoids mainly represented by oleuropein and ligstroside derivatives, which are strong radical scavengers and are also responsible for bitterness and pungency of EVOO [2-4].

Phenolic compounds are used as quality markers for virgin olive oil, and they are of great interest due to their anticancer, antiviral, and anti-inflammatory properties $[5,6]$. Their content is an important factor when evaluating the EVOO quality because they have been correlated with the oil oxidative stability and, in particular, its resistance to lipid peroxidation $[7,8]$. Extra virgin olive oil quality production could be influenced by several factors, for instance: olive cultivar, geographical region, environmental factors (seasonal conditions), irrigation, olive ripeness, harvesting, storage, and extraction procedure [9-11]. Light exposure, elevated temperature, and oxygen are all natural adversaries of EVOO and contribute to its deterioration [12].

The Mediterranean countries head the list of olive oil producers; the International Olive Oil Council classed Algeria as the ninth largest producer country of olive oil in the world, with around 87.5 tons in the 2015/16 season [13-15]. The olive oil production in Algeria is continuously increasing. In fact, the country is following a development policy called "National program for agriculture development" which opens the way for financing and supporting the agricultural sector [16]. Within the framework of this program, the government provides financial aid to farmers who plant olive trees and to the producers of olive oil [17]. Even with this, the commercialization of a high quality of olive oil is still presenting a challenge for the producers in Algeria.

The aim of this study was the chemical characterization of monovarietal oils produced in Algeria and the evaluation of their quality. In particular, the study focused on the comparison of the qualitative characteristics of: (a) Tefahi and Gelb Elfarroudj olive oils (cultivars not known in literature); (b) Chemlal and Zebboudj olive oils (known cultivars); (c) Manzanilla oil (imported cultivar). The authors believe that a quantitative characterization of the bioactive constituents of Algerian olive oils could contribute to their enhancement in a constantly growing international market.

For this, firstly, quality control tests were performed on all olive oils under study. Then, phenolic profile, fatty acid methyl esters pattern, and in vitro antioxidant capacity of the olive oils were determined.

\section{Materials and Methods}

\subsection{Plant Material and Olive Oil Samples}

Olive oil from four Olea europaea cultivars growing in the northeast of Algeria were used in this study (Setif and Batna provinces) (Figure 1). Three cultivars (Chemlal, Tefahi, and Gelb Elfarroudj) are native to the region, while one is locally grown but it is a foreign cultivar (Manzanilla). Furthermore, Zebboudj olive oil (Olea oleaster) was bought from the market and included in this study. The cultivars were growing under the same environmental characteristics in a semiarid region. Drop irrigation was used twice a year: in January (every fortnight) and in August (every 10 days). The method used in this study for olive harvest and extraction was the one used by most of Algerian producers. Healthy olive fruits of all cultivars were hand-picked when the skin of the fruit was black. The oils were extracted 
from $200 \mathrm{~kg}$ of the collected fruits using a commercial modern mill located in the same region. The mill originated from Jeha Company (Alexandria, Egypt) and was equipped with a two-phase extraction system. The extraction of olive oil started with leaf stripping and olive cleaning, then olives passed into a hammer-crusher to obtain a homogenized olive paste. The malaxation time and temperature of the olive paste were $30 \mathrm{~min}$ at $30^{\circ} \mathrm{C}$. After centrifugation, the oil was separated from the paste and water, and then stored in amber glass bottles at room temperature $\left(15-18^{\circ} \mathrm{C}\right)$ in the dark. Soon after the oil extraction, the samples were used in the chemical analytical methods described below.

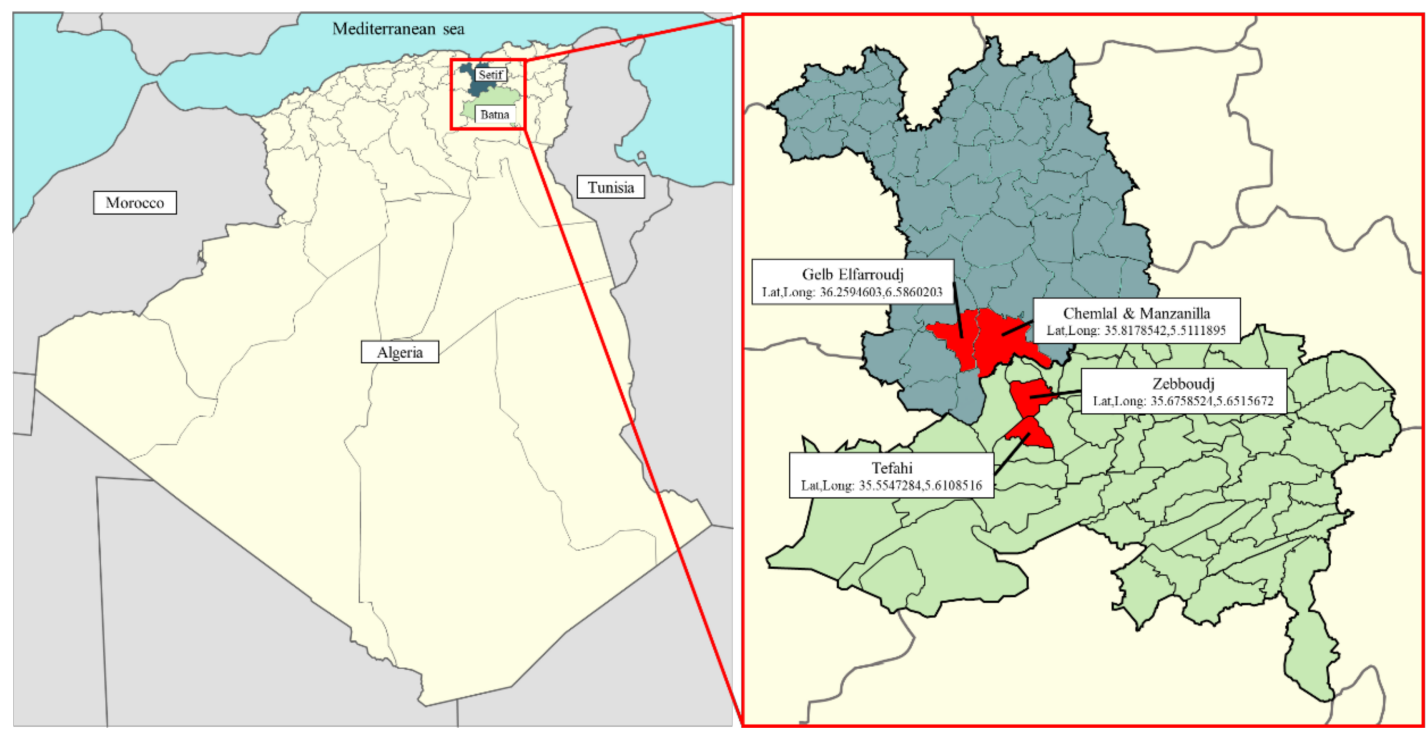

Figure 1. Biogeographical Algerian area where olives are grown.

\subsection{Reagents and Standards}

Formic acid, water, methanol, acetonitrile (LC-MS grade) were purchased from Biosolve B.V. (Valkenswaard, The Netherlands). All solvents, Folin-Ciocalteu reagent, sodium carbonate $\left(\mathrm{Na}_{2} \mathrm{CO}_{3}\right.$ ), 2,2-diphenyl,1-picrylhydrazyl (DPPH), 2,4,6-tri(2-pyridyl)-1,3,5-triazine (TPTZ), ferric chloride $\left(\mathrm{FeCl}_{3} \times 6 \mathrm{H}_{2} \mathrm{O}\right)$, gallic acid, acetic acid, ferric sulfate $\left(\mathrm{FeSO}_{4} \times 7 \mathrm{H}_{2} \mathrm{O}\right)$, sodium acetate, 2,2'-azino-bis(3-ethylbenzothiazoline-6-sulphonic acid) (ABTS), potassium persulfate, phosphate-buffered saline (PBS), tween 40, $\beta$-carotene, Trolox, and chemical standards (cinnamic acid, $p$-coumaric acid, $p$-hydroxybenzoic acid, ferulic acid, syringic acid, vanillic acid, caffeic acid apigenin, apigenin 7-glucoside, diosmetin, hydroxytyrosol, tyrosol, luteolin, oleuropein, vanillin, pinoresinol), were purchased from Sigma-Aldrich (St. Louis, MO, USA).

\subsection{Quality Parameters}

Free acidity, given as g oleic acid $100 \mathrm{~g}^{-1}$ of oil, peroxide value (PV) expressed as meq $\mathrm{O}_{2} \mathrm{~kg}^{-1}$ of oil, $\Delta \mathrm{K}$ and $\mathrm{K}_{232}, \mathrm{~K}_{270}$ extinction coefficients calculated from absorptions at $232 \mathrm{~nm}$ and $270 \mathrm{~nm}$ were measured as described by the Regulation EC no. 2016/2095 [18].

\subsection{FAMEs Composition}

Fatty acid methyl esters (FAMEs) were analyzed using the GC-MS method after extraction and hydrolysis of triacyl glycerols using potassium hydroxide in methanol.

A mass of $0.1 \mathrm{~g}$ of oil samples were diluted in $1 \mathrm{~mL}$ of $\mathrm{n}$-heptane and $0.1 \mathrm{~mL}$ of $2 \mathrm{~N} \mathrm{KOH}$ in $\mathrm{MeOH}$ solution was added and mixed in a vortex for $2 \mathrm{~min}$. An aliquot of $500 \mu \mathrm{L}$ of organic phase containing fatty acid methyl esters was diluted with $500 \mu \mathrm{L}$ n-heptane. Immediately, GC-MS analyses were carried out using a DSQ II single quadrupole system (Thermo Fisher Scientific, Bremen, Germany). The temperature of ion source and injector were $260^{\circ} \mathrm{C}$ and $270{ }^{\circ} \mathrm{C}$, respectively. The capillary column 
used was a ZB-WAX (30 $\mathrm{m} \times 0.25 \mathrm{~mm}$ i.d., film thickness $0.25 \mu \mathrm{m}$ ) (Phenomenex, Italy). The oven program temperature started at $165^{\circ} \mathrm{C}$ (held for $10 \mathrm{~min}$ ), it was increased to $200^{\circ} \mathrm{C}$ at $1.5^{\circ} \mathrm{C} / \mathrm{min}$, then increased to $250{ }^{\circ} \mathrm{C}$ at $10{ }^{\circ} \mathrm{C} / \mathrm{min}$ and kept for $20 \mathrm{~min}$ at $250^{\circ} \mathrm{C}$ under isothermal conditions. Ionization energy was $70 \mathrm{eV}$ and the mass range scanned was $35-550 \mathrm{~m} / \mathrm{z}$. Helium flow rate of $1 \mathrm{~mL} \mathrm{~min}^{-1}$ was used. Monovarietal olive oil samples of $1 \mu \mathrm{L}$ were injected with a split ratio of 1:100 in triplicate. Fatty acid methyl esters identification was carried out using a mass spectrum database and 37-component fatty acid methyl esters mix (Sigma Aldrich Milan, Milan, Italy).

\subsection{Individual Phenolic Compounds Characterization by UHPLC-HESI-MS}

Liquid-liquid extraction method was used to isolate the phenolic fraction of olive oils. For this purpose, $2 \mathrm{~g}$ of each olive oil was mixed with $5 \mathrm{~mL}$ of a solution of methanol-water $(80: 20 \mathrm{v} / \mathrm{v})$; then, the samples were shaken in a vortex for $1 \mathrm{~min}$, placed in an ultrasonic bath for $15 \mathrm{~min}$, and centrifuged at $5000 \mathrm{rpm}$ for $25 \mathrm{~min}$. The resulting aqueous solutions were filtered over PTFE syringe filter $0.45 \mu \mathrm{m}$ and quickly analyzed by ultra-high-performance liquid chromatography, using a heated electrospray probe and high-resolution mass spectrometer (UHPLC-HESI-MS) for quali-quantitative determination of phenolic compounds, with three different dilution factors $(1: 2,1: 10,1: 100 v / v)$ to encompass the concentration variability. Triplicate samples of monovarietal olive oil were used for phenolic extractions. Experimental conditions used for qualitative determination of the phenolic constituents have been described in literature [19-21].

Briefly, UHPLC used was a Dionex Ultimate 3000 System equipped with an auto sampler controlled by Chromeleon 7.2 Software (Thermo Fisher Scientific, Bremen, Germany and Dionex Softron GmbH, Germering, Germany). A column Luna C18 $50 \times 1 \mathrm{~mm}, 2.5 \mu \mathrm{m}$ was used. A flow rate of $50 \mu \mathrm{L} \mathrm{min}{ }^{-1}$ was set for separation of the selected compounds. The separation was achieved using eluent $A$ (water with $0.1 \%$ acetic acid $(v / v) \mathrm{pH} 3.2)$ and eluent $\mathrm{B}$ (acetonitrile). The gradient elution program was: 0-2 min 5\% B; 2-4.5 min linear increase to 10\% B; 4.5-16 min linear increase to 25\% B; 16-29 min linear increase to $95 \% \mathrm{~B} ; 29-31 \mathrm{~min}$ decrease to $5 \% \mathrm{~B} ; 31-33 \mathrm{~min}$ hold $5 \% \mathrm{~B}$ coming back to the initial conditions and being equilibrated. The column temperature was set at $35^{\circ} \mathrm{C}$ and the injection volume at $1 \mu \mathrm{L}$. Heated electrospray ion source (HESI) was used for the ionization. HESI parameters were optimized as follows: sheath gas flow rate 35 arbitrary units; auxiliary gas unit flow rate 4 arbitrary units; capillary temperature $250{ }^{\circ} \mathrm{C}$; auxiliary gas heater temperature $259^{\circ} \mathrm{C}$; spray voltage $3.5 \mathrm{kV}$; and S lens RF level 30. MS in negative mode was selected for analysis of low-molecular phenolic compounds $[19,21]$. Detection of phenolic compounds was performed using a quadrupole Orbitrap mass spectrometer (Q Exactive; Thermo Scientific, Bremen, Germany). Full scan (100-800 m/z) acquisition method and a targeted single ion monitoring (SIM) analysis were performed using the mass inclusion list of the target analytes.

Phenolic compounds were quantified using solutions containing all commercial standards at six different concentration levels $\left(5,2.5,1,0.5,0.25,0.1 \mu \mathrm{g} \mathrm{mL} \mathrm{L}^{-1}\right)$. Each point of the external calibration graph corresponded to the average of five independent injections.

In the case of secoiridoids derivatives, where commercial standards were not available, their equivalent values were estimated. Monovarietal olive oil contents of 3,4-DHPEA-EA (oleuropein aglycon and stereoisomers), 3,4-DHPEA-EDA (oleacein), p-HPEA-EA (ligstroside aglycon and stereoisomers), deacetoxy-10-hydroxy oleuropein aglycon (DAc-10-OH Ole Agly), and elenolic acid (EA) were expressed as a p-HPEA-EDA (oleocanthal) equivalent ( $\mathrm{mg} \mathrm{kg}^{-1}$ of oil) [18]. Isolation of p-HPEA-EDA (oleocanthal) from olive oil was carried out according to a reported procedure developed in literature [19-21]. Briefly, $500 \mathrm{~mL}$ of olive oil was mixed with $250 \mathrm{~mL}$ hexane and $250 \mathrm{~mL}$ methanol. The mixture was sonicated for $15 \mathrm{~min}$ and after partition, the methanolic phase was centrifuged at $3000 \mathrm{rpm}$ for $10 \mathrm{~min}$. The hexane phase was extracted with $200 \mathrm{~mL}$ of methanol again. Combined methanolic phases were evaporated and the oily residue was extracted with $25 \mathrm{~mL}$ methanol-water (1:1) and $50 \mathrm{~mL}$ of hexane. 
The aqueous $\mathrm{MeOH}$ layer was used for isolation of oleocanthal. Preparative chromatography was performed on an HPLC Agilent 1100 binary pump equipped with a UV-Vis detector. The chromatographic column was a reverse-phase Supelcosil LC 318 column, $25 \mathrm{~cm}, 4.6 \mathrm{~mm}, 3 \mu \mathrm{m}$ particle size. HPLC elution was performed at $5 \mathrm{~mL} / \mathrm{min}$ with a binary gradient system with water (solvent A) and acetonitrile (solvent B). The gradient was: $0-5 \mathrm{~min}, 30 \% \mathrm{~B} ; 5-30 \mathrm{~min}, 100 \% \mathrm{~B} ; 35-40$ $\mathrm{min}, 30 \% \mathrm{~B}$. The eluate was monitored at $278 \mathrm{~nm}$ and fractions of about $3 \mathrm{~mL}$ were collected from the detector. After fractions collection, the solvents were evaporated under reduced pressure using a rotary evaporator, and finally the residue was stored at $-20^{\circ} \mathrm{C}$. The obtained fractions were analyzed by UHPLC-ESI-MS/MS and those with similar composition were combined for further preparative chromatography in the same conditions. Identity and purity of the oleocanthal were verified through spectroscopic techniques such as ${ }^{1} \mathrm{HNMR},{ }^{13} \mathrm{C}$ NMR, and UHPLC-HESI-MS.

Oleocanthal was used as external standard to prepare further calibration solutions $(10,5,2.5,1$, $\left.0.5,0.25,0.1 \mu \mathrm{g} \mathrm{mL}^{-1}\right)$. The deprotonated molecule $[\mathrm{M}-\mathrm{H}]^{-}$detection was based on calculated exact mass and on retention time of target compounds.

\subsection{Olive Oil Extracts for Determination of Total Phenolic Content and for Antioxidant Assays}

The oil samples $(2 \mathrm{~g})$ were added to $5 \mathrm{~mL}$ of a methanol/water $(80: 20, v / v)$ mixture in a centrifuge tube. After vigorous mixing, they were centrifuged for $25 \mathrm{~min}$ at $5000 \mathrm{rpm}$. The hydroalcoholic phase was collected, washed with $2 \mathrm{~mL}$ of $\mathrm{n}$-hexane to remove the residual oil, and then concentrated under reduced pressure using a rotary evaporator at $35^{\circ} \mathrm{C}$. The issued phenolic fraction extracts (PFEs) were fully dried using a vacuum desiccator. The oil PFEs were dissolved in the methanol/water mixture to use them in the determination of total phenolic content and in antioxidant assays.

\subsection{Total Phenols Content}

The total phenol compounds of the oil's phenolic fraction extracts (PFE), was determined by the Folin-Ciocalteu colorimetric assay [22]. Briefly, fifty microliter of the solutions containing different concentrations ( $5 \mathrm{mg} \mathrm{mL}^{-1}, 3 \mathrm{mg} \mathrm{mL}^{-1}, 1 \mathrm{mg} \mathrm{mL}^{-1}, 0.5 \mathrm{mg} \mathrm{mL}^{-1}$, and $0.25 \mathrm{mg} \mathrm{mL}^{-1}$ ) oil's PFE to be tested were added to $450 \mu \mathrm{L}$ of deionized water, $500 \mu \mathrm{L}$ of Folin-Ciocalteau reagent, and $500 \mu \mathrm{L}$ of $10 \%$ aqueous sodium carbonate solution. Samples were then maintained at room temperature for $1 \mathrm{~h}$ and absorbance was measured at $786 \mathrm{~nm}$ (UV-Vis Spectrophotometer, Shimadzu Japan) against blank containing $50 \mu \mathrm{L}$ of the methanol (sample solvent). Gallic acid at different concentrations ( $300 \mu \mathrm{g} \mathrm{mL} \mathrm{m}^{-1}$, $150 \mu \mathrm{g} \mathrm{mL}^{-1}, 75 \mu \mathrm{g} \mathrm{mL}^{-1}$, and $25 \mu \mathrm{g} \mathrm{mL}^{-1}$ ) was used as standard. The experiment was performed in triplicate and the results were expressed as $\mu \mathrm{g}$ gallic acid equivalents/mg of phenolic fraction extracts ( $\mu \mathrm{g}$ GAE $\mathrm{mg}^{-1}$ PFE).

\subsection{Antioxidant Activity}

\subsubsection{2,2-Diphenyl-1-Picrylhydrazyl Test}

The free-radical-scavenging capacity of the oil's phenolic fraction extracts (PFEs) was determined by the 2,2-diphenyl-1-picrylhydrazyl (DPPH) assay as reported in literature [23]. A volume of $1.5 \mathrm{~mL}$ of $\mathrm{DPPH}^{\bullet}$ solution (100 mM in methanol) was mixed with $37.5 \mu \mathrm{L}$ of various concentrations $\left(87 \mathrm{mg} \mathrm{mL}^{-1}\right.$, $60 \mathrm{mg} \mathrm{mL}^{-1}, 50 \mathrm{mg} \mathrm{mL}^{-1}, 45 \mathrm{mg} \mathrm{mL}^{-1}, 30 \mathrm{mg} \mathrm{mL}^{-1}, 25 \mathrm{mg} \mathrm{mL}^{-1}, 10 \mathrm{mg} \mathrm{mL}^{-1}, 5 \mathrm{mg} \mathrm{mL}^{-1}$ ) of oil's PFE, or with methanol as control. After $20 \mathrm{~min}$ of incubation at room temperature, the absorbance was recorded at $517 \mathrm{~nm}$ with a UV-Vis spectrophotometer (Shimadzu, Japan). Results were expressed as mmol Trolox equivalents $\mathrm{mg}^{-1}$ of phenolic fraction extracts ( $\mathrm{mmol} \mathrm{TE} \mathrm{mg}^{-1} \mathrm{PFE}$ ), using the calibration curve prepared with Trolox as standard using different concentrations $\left(1.5 \mu \mathrm{g} \mathrm{mL} L^{-1}, 1 \mu \mathrm{g} \mathrm{mL}^{-1}, 0.5 \mu \mathrm{g}\right.$ $\left.\mathrm{mL}^{-1}, 0.25 \mu \mathrm{g} \mathrm{mL}^{-1}, 0.125 \mu \mathrm{g} \mathrm{mL} \mathrm{m}^{-1}\right)$. Each determination was performed in triplicate. 


\subsubsection{Trolox Equivalents Antioxidant Capacity}

The Trolox equivalents antioxidant capacity (TEAC), also known as the ability of the oil's PFEs to scavenge the 2,2'-azinobis-(3-ethylbenzothiazine-6-sulfonic acid radical $\left(\mathrm{ABTS}^{+}\right.$), was evaluated as previously described [24]. The $\mathrm{ABTS}^{+}$radical cation was produced by the oxidation of $\mathrm{ABTS}^{+}$ $(1.7 \mathrm{mM})$ with potassium persulfate $(4.3 \mathrm{mM})$ in water. The mixture was allowed to stand in the dark at room temperature and the $\mathrm{ABTS}^{+}$solution was diluted with phosphate-buffered saline (PBS) at $\mathrm{pH}$ 7.4 to give absorbance of $0.7 \pm 0.02$ at $734 \mathrm{~nm}$. An aliquot of $50 \mu \mathrm{mL}$ of a solution containing different concentrations (50-0.5 mg mL ${ }^{-1}$ ) of the oil's PFE or methanol (blank) was added to $2 \mathrm{~mL}$ of the ABTS ${ }^{+}$ solution, and the absorbance was recorded at $734 \mathrm{~nm}$ in a UV/Vis spectrophotometer (Shimadzu, Japan) after allowing the reaction to stand for $6 \mathrm{~min}$ in the dark at room temperature. Results were expressed as mmol Trolox equivalents/milligram of phenolic fraction extracts ( $\mathrm{mmol} \mathrm{TEmg}^{-1} \mathrm{PFE}$ ) using the calibration curve prepared with Trolox standard at different concentrations $\left(0.215 \mu \mathrm{g} \mathrm{mL}^{-1}, 0.0625 \mu \mathrm{g}\right.$ $\mathrm{mL}^{-1}, 0.0312 \mu \mathrm{g} \mathrm{mL}-1,0.015 \mu \mathrm{g} \mathrm{mL}^{-1}$,). Each determination was repeated at least three times.

\subsubsection{Ferric-Reducing/Antioxidant Power}

The ferric-reducing/antioxidant power (FRAP) of the phenolic fraction extracts was evaluated as previously described [25]. The fresh working solution ferric-reducing/antioxidant power (FRAP) reagent was prepared by mixing $2.5 \mathrm{~mL}$ of $10 \mathrm{mM}$ 2,4,6-tripyridyl-s-triazine solution (prepared in $40 \mathrm{mM} \mathrm{HCl}$ ) with $25 \mathrm{~mL}$ of $0.3 \mathrm{M}$ acetate buffer ( $\mathrm{pH} 3.6$ ) and $2.5 \mathrm{~mL}$ of $20 \mathrm{mM} \mathrm{FeCl}_{3} \cdot 6 \mathrm{H}_{2} \mathrm{O}$ solution, and then preheated at $37^{\circ} \mathrm{C}$ before use. A volume of $50 \mu \mathrm{L}$ of a methanolic solution containing different concentrations (25-1 mg mL ${ }^{-1}$ ) of the oil's PFE to be tested, or of the solvent, were added to $1 \mathrm{~mL}$ of FRAP reagent, and the absorbance was measured at $593 \mathrm{~nm}$ in a spectrophotometer (Shimadzu, Japan) after incubation at $20^{\circ} \mathrm{C}$ for $4 \mathrm{~min}$. A standard curve was prepared using various concentrations $(1 \mu \mathrm{g}$ $\mathrm{mL}^{-1}, 0.5 \mu \mathrm{g} \mathrm{mL} L^{-1}, 0.25 \mu \mathrm{g} \mathrm{mL}^{-1}, 0.1 \mu \mathrm{g} \mathrm{mL}^{-1}$ ) of $\mathrm{FeSO}_{4} \times 7 \mathrm{H}_{2} \mathrm{O}$. Each determination was performed in triplicate; the results were expressed as $\mathrm{mmol} \mathrm{Fe}^{2+} /$ milligram of phenolic fraction extracts (mmol $\mathrm{Fe}^{2+} / \mathrm{mg}$ of PFE).

\subsubsection{Beta-Carotene Bleaching Assay}

The potential of the oil's PFE in the $\beta$-carotene bleaching assay (BCB) was determined as described in literature [26]. A mass of $1 \mathrm{mg}$ of $\beta$-carotene was dissolved in $10 \mathrm{~mL}$ of chloroform. Then, $5 \mathrm{~mL}$ of solution was added to $40 \mu \mathrm{L}$ of linoleic acid and $400 \mu \mathrm{L}$ of Tween 40 . Chloroform was removed using a rotary evaporator and $100 \mathrm{~mL}$ of distilled water was added.

A volume of $5 \mathrm{~mL}$ was added to $200 \mu \mathrm{L}$ of a solution containing different concentrations (25-0.5 mg mL ${ }^{-1}$ ) of oil's PFE, whereas $5 \mathrm{~mL}$ of DMSO was used as blank. The absorbance was measured at $470 \mathrm{~nm}$ and results were expressed as 50\% mean inhibition concentration (IC 50) with confidence limits (CL) at 95\% calculated by Litchfield and Wilcoxon test. Each determination was carried out in triplicate and repeated at least three times.

\subsection{Statistical Analysis}

The results are expressed as mean values \pm standard deviation (SD) from three separate experiments. The results of total phenolic content and antioxidant activity were analyzed using Student's $t$ test. Differences were considered to be statistically significant at $p<0.05$.

\section{Results}

\subsection{Quality Parameters}

The qualitative parameters of the oils studied, obtained using analytical methods described by the International Olive Council [27], highlight some defects of Algerian monovarietal oils. 
The results are summarized in Table 1 . The oil obtained from the Zebboudj cultivar had a free acidity value ( $1.25 \mathrm{~g}$ oleic acid $100 \mathrm{~g}^{-1}$ of oil) higher than the established limit, whereas the oils obtained from the Manzanilla and Gelb Elfarroudj cultivars had free acidity values 0.80 and 0.75 respectively; the first value was equal to the maximum allowed limit and the second one was very close to it. The peroxide values were also quite high even if below the maximum allowed limit; in particular, they were between 12.75 meq $\mathrm{O}_{2} \mathrm{~kg}^{-1}$ and 15.50 meq $\mathrm{O}_{2} \mathrm{~kg}^{-1}$. The conjugated trienes $\mathrm{K}_{270}$ and dienes $\mathrm{K}_{232}$ showed values in the range of $0.12-0.21$ and $1.47-2.30$, respectively, while $\Delta \mathrm{K}$ results were in the range of $-0.007-0.11$.

Table 1. Results of qualitative parameters of monovarietal Algerian olive oils under study.

\begin{tabular}{cccccc}
\hline Cultivars & Free Acidity (\%) & $\left.\mathbf{P V ~ ( m e q ~} \mathbf{~}_{\mathbf{2}} / \mathbf{k g}\right)$ & $\mathbf{K}_{\mathbf{2 3 2}}$ & $\mathbf{K}_{\mathbf{2 7 0}}$ & $\boldsymbol{\Delta} \mathbf{K}$ \\
\hline Tefahi & $0.48 \pm 0.03 \mathrm{c}$ & $12.68 \pm 1.23 \mathrm{~b}$ & $1.98 \pm 0.17 \mathrm{~b}$ & $0.17 \pm 0.02 \mathrm{a}$ & $-0.002 \pm 0.01 \mathrm{c}$ \\
Chemlal & $0.50 \pm 0.05 \mathrm{c}$ & $12.75 \pm 1.13 \mathrm{~b}$ & $2.29 \pm 0.28 \mathrm{a}$ & $0.19 \pm 0.01 \mathrm{a}$ & $0.001 \pm 0.01 \mathrm{~b}$ \\
Gelb Elfarroudj & $0.75 \pm 0.06 \mathrm{~b}$ & $15.50 \pm 1.53 \mathrm{a}$ & $1.97 \pm 0.26 \mathrm{~b}$ & $0.21 \pm 0.03 \mathrm{a}$ & $0.003 \pm 0.03 \mathrm{~b}$ \\
Manzanilla & $0.80 \pm 0.04 \mathrm{~b}$ & $15.50 \pm 0.24 \mathrm{a}$ & $1.47 \pm 0.24 \mathrm{c}$ & $0.12 \pm 0.01 \mathrm{~b}$ & $-0.007 \pm 0.01 \mathrm{~d}$ \\
Zebboudj & $1.25 \pm 0.11 \mathrm{a}$ & $12.51 \pm 0.32 \mathrm{~b}$ & $0.39 \pm 0.03 \mathrm{~d}$ & $0.11 \pm 0.05 \mathrm{~b}$ & $0.11 \pm 0.05 \mathrm{a}$ \\
\hline
\end{tabular}

Free acidity $=$ g oleic acid $100 \mathrm{~g}^{-1}$ of oil, peroxide value $(\mathrm{PV})=\mathrm{meq} \mathrm{O}_{2} \mathrm{~kg}^{-1}$ of oil. Results were expressed as mean \pm SD. Different letters in columns indicate statistical differences at $p<0.05$ (Student's $t$ test) among cultivars.

\subsection{Fatty Acid Composition}

Using GC-MS, 12 fatty acids were detected as shown in Table 2. The composition of the samples was a combination of four saturated fatty acids (palmitic acid C16:0, margaric acid C17:0, stearic acid C18:0, and arachidic acid C20:0); six mono-unsaturated fatty acids (palmitoleic acid C16:1 (7-cis) ( $\omega-9)$, palmitoleic acid C16:1 (9-cis) ( $\omega-7)$, heptadecenoic acid C17:1, oleic acid C18:1 ( $\omega-7)$, oleic acid C18:1 ( $\omega-9)$, and 11-eicosenoic acid C20:1 ( $\omega-9))$, and two poly-unsaturated fatty acids (linoleic acid C18:2 ( $\omega-6)$ and $\alpha$-linolenic acid C18:3 ( $\omega-3))$. The monounsaturated fatty acids were higher in the monovarietal oils of Gelb Elfarroudj, Tefahi, and Manzanilla, due to the high content of oleic acid C18:1 $(\omega-9)$. Polyunsaturated fatty acids content was highest in Zebboudj oil mainly due to the high content of linoleic acid. The percentages of fatty acids in our work are very close to those of other Algerian cultivars [28]. Our results in the concentrations of palmitic acid, linoleic acid, and $\alpha$-linolenic are also in agreement with those reported in other studies about Chemlal Algerian olive oil [29].

Table 2. Fatty acid methyl esters (in percentage) identified by GC-MS in the monovarietal olive oils under study.

\begin{tabular}{|c|c|c|c|c|c|}
\hline \multirow[b]{2}{*}{ Fatty Acids } & \multicolumn{5}{|c|}{ Cultivars } \\
\hline & Tefahi & Chemlal & Gelb Elfarroudj & Manzanilla & Zebboudj \\
\hline C16:0 & $12.27 \pm 0.04 b$ & $15.75 \pm 0.02 a$ & $12.70 \pm 0.05 b$ & $9.97 \pm 0.31 c$ & $11.59 \pm 0.09 \mathrm{~b}$ \\
\hline $\mathrm{C} 16: 1(\omega-7)$ & $0.14 \pm 0.01 \mathrm{~b}$ & $0.35 \pm 1.5 \mathrm{a}$ & $0.16 \pm 0.01 \mathrm{~b}$ & $0.20 \pm 0.01 b$ & nf \\
\hline C16:1 ( $\omega-9)$ & $1.12 \pm 0.01 b$ & $1.05 \pm 0.22 \mathrm{a}$ & $1.21 \pm 0.05 b$ & $0.57 \pm 0.01 c$ & $0.10 \pm 0.01 \mathrm{~d}$ \\
\hline C17:0 & $0.03 \pm 0.01 b$ & $0.91 \pm 1.56 \mathrm{a}$ & $0.08 \pm 0.02 b$ & $0.05 \pm 0.04 b$ & $0.08 \pm 0.01 b$ \\
\hline C17:1 & $0.05 \pm 0.01 b$ & $0.15 \pm 0.09 \mathrm{a}$ & $0.10 \pm 0.01 b$ & $0.08 \pm 0.01 b$ & $0.05 \pm 0.01 b$ \\
\hline C18:0 & $2.46 \pm 0.04 \mathrm{c}$ & $4.95 \pm 0.88 \mathrm{a}$ & $2.68 \pm 0.05 c$ & $2.39 \pm 0.03 c$ & $4.27 \pm 0.01 b$ \\
\hline $\mathrm{C} 18: 1(\omega-7)$ & $3.17 \pm 0.11 \mathrm{a}$ & $2.37 \pm 0.55 b$ & $3.48 \pm 0.39 \mathrm{a}$ & $2.31 \pm 0.11 b$ & $1.55 \pm 0.03 c$ \\
\hline C18:1(w-9) & $66.93 \pm 0.26 b$ & $59.97 \pm 1.11 c$ & $66.03 \pm 0.49 b$ & $74.9 \pm 0.35 \mathrm{a}$ & $26.65 \pm 0.08 c$ \\
\hline $\mathrm{C} 18: 2(\omega-6)$ & $12.43 \pm 0.17 b$ & $9.34 \pm 0.33 c$ & $12.10 \pm 0.09 \mathrm{~b}$ & $8.18 \pm 0.06 c$ & $48.51 \pm 0.02 \mathrm{a}$ \\
\hline $\mathrm{C} 18: 3(\omega-3)$ & $0.84 \pm 0.09 \mathrm{~b}$ & $0.83 \pm 0.01 b$ & $0.97 \pm 0.10 \mathrm{~b}$ & $0.81 \pm 0.01 b$ & $6.35 \pm 0.01 \mathrm{a}$ \\
\hline C20:0 & $0.26 \pm 0.04 \mathrm{a}$ & $0.32 \pm 0.01 \mathrm{a}$ & $0.33 \pm 0.03 a$ & $0.27 \pm 0.02 \mathrm{a}$ & $0.33 \pm 0.01 \mathrm{a}$ \\
\hline C20:1 (w-9) & $0.27 \pm 0.07 b$ & $0.25 \pm 0.01 b$ & $0.24 \pm 0.05 b$ & $0.31 \pm 0.02 \mathrm{a}$ & $0.16 \pm 0.01 c$ \\
\hline$\sum \mathrm{SFA}^{+} \%$ & $15.02 \mathrm{~b}$ & $21.93 \mathrm{a}$ & $15.69 \mathrm{~b}$ & $12.58 \mathrm{c}$ & $16.27 \mathrm{~b}$ \\
\hline$\sum$ MFA $\ddagger \%$ & $71.7 \mathrm{a}$ & $64.14 b$ & $71.2 \mathrm{a}$ & $78.4 \mathrm{a}$ & $28.5 c$ \\
\hline$\sum$ PFA $§ \%$ & $13.27 b$ & $10.17 \mathrm{c}$ & $13.07 \mathrm{~b}$ & $8.99 \mathrm{c}$ & $54.86 \mathrm{a}$ \\
\hline
\end{tabular}

The results are expressed as mean $\% \pm$ SD of total fatty acid methyl esters $(n=3) .{ }^{\dagger}$ : saturated fatty acid; ${ }^{\ddagger}$ : monounsaturated fatty acid; $\S$ : polyunsaturated fatty acid; $\mathrm{nf}=$ not found. Different letters for each fatty acid indicate statistical differences at $p<0.05$ (Student's $t$ test) among cultivars. 


\subsection{Individual Phenolic Compounds Identification}

In our study, UHPLC-HESI-MS was used for identification of the phenolic compounds. Table 3 shows the calibration data of reference compounds used as external standards in the UHPLC-HESI-MS characterization.

Table 3. Calibration data of reference compounds used as external standards for identification of phenolic compounds.

\begin{tabular}{|c|c|c|c|c|c|}
\hline $\begin{array}{l}\text { Phenolic } \\
\text { Compounds }\end{array}$ & $\begin{array}{l}\text { Molecular } \\
\text { Formula }\end{array}$ & $\begin{array}{l}\text { Experimental } \mathrm{m} / \mathrm{z} \\
{[\mathrm{M}-\mathrm{H}]^{-}}\end{array}$ & $\begin{array}{l}\text { Retention } \\
\text { Time }\end{array}$ & Linear Regression & $\left(\mathrm{r}^{2}\right)$ \\
\hline Tyrosol & $\mathrm{C}_{8} \mathrm{H}_{10} \mathrm{O}_{2}$ & 137.05933 & 12.05 & $\mathrm{Y}=-124,926+8556 \times \mathrm{X}$ & 0.9937 \\
\hline Hydroxytyrosol & $\mathrm{C}_{8} \mathrm{H}_{10} \mathrm{O}_{3}$ & 153.05438 & 9.15 & $Y=-5.29 \times 10^{6}+7.31 \times 10^{7} \times X$ & 0.9974 \\
\hline $\begin{array}{l}p \text {-Coumaric } \\
\text { Acid }\end{array}$ & $\mathrm{C}_{9} \mathrm{H}_{8} \mathrm{O}_{3}$ & 163.03847 & 18.30 & $Y=-5.83 \times 10^{6}+8.72 \times 10^{7} \times X$ & 0.9959 \\
\hline Caffeic Acid & $\mathrm{C}_{9} \mathrm{H}_{8} \mathrm{O}_{4}$ & 179.03392 & 14.90 & $Y=-2.65 \times 10^{6}+8.46 \times 10^{7} \times X$ & 0.9750 \\
\hline Ferulic Acid & $\mathrm{C}_{10} \mathrm{H}_{10} \mathrm{O}_{4}$ & 193.05026 & 19.10 & $Y=-5.99 \times 10^{6}+5.15 \times 10^{7} \times X$ & 0.9983 \\
\hline Vanillic Acid & $\mathrm{C}_{8} \mathrm{H}_{8} \mathrm{O}_{4}$ & 167.03388 & 14.30 & $Y=-412,147+2.85 \times 10^{6} \times X$ & 0.9812 \\
\hline $\begin{array}{l}p \text {-Hydroxybenzoic } \\
\text { Acid }\end{array}$ & $\mathrm{C}_{7} \mathrm{H}_{6} \mathrm{O}_{3}$ & 137.02304 & 13.50 & $Y=648,298+6.49 \times 10^{7} \times X$ & 0.9982 \\
\hline Syringic Acid & $\mathrm{C}_{9} \mathrm{H}_{10} \mathrm{O}_{5}$ & 197.04519 & 14.56 & $Y=746,927+5.54 \times 10^{6} \times X$ & 0.9852 \\
\hline Cinnamic Acid & $\mathrm{C}_{9} \mathrm{H}_{8} \mathrm{O}_{2}$ & 147.04049 & 3.50 & $Y=-1.69 \times 10^{6}+2.42 \times 10^{6} \times X$ & 0.9888 \\
\hline Gallic Acid & $\mathrm{C}_{7} \mathrm{H}_{6} \mathrm{O}_{5}$ & 169.01319 & 7.45 & $Y=-1.94 \times 10^{6}+4.30 \times 10^{7} \times X$ & 0.9968 \\
\hline $\begin{array}{l}\text { Protocatechuic } \\
\text { Acid }\end{array}$ & $\mathrm{C}_{7} \mathrm{H}_{6} \mathrm{O}_{4}$ & 153.01763 & 10.35 & $Y=-2.85 \times 10^{6}+2.09 \times 10^{7} \times X$ & 0.9929 \\
\hline Oleocanthal & $\mathrm{C}_{17} \mathrm{H}_{20} \mathrm{O}_{5}$ & 303.12387 & 23.50 & $Y=-3.19 \times 10^{6}+3.09 \times 10^{7} \times X$ & 0.9984 \\
\hline Vanillin & $\mathrm{C}_{8} \mathrm{H}_{8} \mathrm{O}_{3}$ & 151.03867 & 17.22 & $Y=-318,221+5.02 \times 10^{6} \times X$ & 0.9994 \\
\hline Pinoresinol & $\mathrm{C}_{20} \mathrm{H}_{22} \mathrm{O}_{6}$ & 357.13445 & 23.05 & $\mathrm{Y}=-61,525.2+634911 \times \mathrm{X}$ & 0.9988 \\
\hline Oleuropein & $\mathrm{C}_{25} \mathrm{H}_{32} \mathrm{O}_{13}$ & 539.17732 & 20.60 & $Y=-3.11 \times 10^{6}+3.10 \times 10^{7} \times X$ & 0.9985 \\
\hline Luteolin & $\mathrm{C}_{15} \mathrm{H}_{10} \mathrm{O}_{6}$ & 285.04037 & 23.30 & $Y=3.61 \times 10^{6}+1.24 \times 10^{8} \times X$ & 0.9992 \\
\hline Diosmetin & $\mathrm{C}_{16} \mathrm{H}_{12} \mathrm{O}_{6}$ & 299.05621 & 24.05 & $\mathrm{Y}=1.435 \times 108 \times \mathrm{X}$ & 0.9853 \\
\hline Apigenin & $\mathrm{C}_{15} \mathrm{H}_{10} \mathrm{O}_{5}$ & 269.04565 & 24.00 & $Y=2.37 \times 10^{7}+2.18 \times 10^{8} \times X$ & 0.9989 \\
\hline \multicolumn{2}{|c|}{ Apigenin-7-glucoside $\mathrm{C}_{7} \mathrm{H}_{6} \mathrm{O}_{5}$} & 431.09854 & 22.90 & $Y=9.18 \times 10^{6}+7.56 \times 10^{7} \times X$ & 0.9954 \\
\hline
\end{tabular}

The UHPLC-HESI-MS analysis allowed the identification of 13 phenolic compounds and the class of secoiridoids is the most represented as shown in Table 4.

Table 4. Phenolic compounds $\left(\mathrm{mgkg}^{-1}\right)$ identified in the monovarietal olive oils by UHPLC-ESI-MS.

\begin{tabular}{|c|c|c|c|c|c|c|}
\hline \multicolumn{2}{|c|}{ Phenolic Compound } & \multicolumn{5}{|c|}{ Cultivars } \\
\hline & & Tefahi & Chemlal & $\begin{array}{c}\text { Gelb } \\
\text { Elfarroudj }\end{array}$ & Manzanilla & Zebboudj \\
\hline $\begin{array}{l}\text { Phenolic } \\
\text { alcohol }\end{array}$ & Hydroxytyrosol & $0.41 \mathrm{a}$ & $\mathrm{nf}$ & $\mathrm{nf}$ & $0.24 \mathrm{a}$ & $\mathrm{Nf}$ \\
\hline \multirow{5}{*}{$\begin{array}{l}\text { Phenolic } \\
\text { acids }\end{array}$} & $p$-Coumaric acid & $0.54 \mathrm{~b}$ & $\mathrm{nf}$ & $0.61 \mathrm{a}$ & $\mathrm{nf}$ & $0.41 \mathrm{~b}$ \\
\hline & Caffeic acid & $0.07 \mathrm{c}$ & $0.98 \mathrm{c}$ & $1.22 \mathrm{a}$ & $0.8 \mathrm{~b}$ & $0.72 \mathrm{a}$ \\
\hline & Ferulic acid & $0.41 \mathrm{a}$ & $0.55 \mathrm{c}$ & $0.68 \mathrm{~b}$ & $\mathrm{nf}^{\dagger}$ & $\mathrm{nf}$ \\
\hline & Vanillic acid & $\mathrm{nf}$ & $\mathrm{nf}$ & $0.70 \mathrm{c}$ & $\mathrm{nf}^{\dagger}$ & $1.43 \mathrm{~b}$ \\
\hline & $p$-Hydroxy benzoic acid & $\mathrm{nf}$ & $\mathrm{nf}$ & $0.42 \mathrm{a}$ & $0.32 \mathrm{c}$ & $0.45 \mathrm{a}$ \\
\hline \multirow{6}{*}{ Secoiridoids } & $\begin{array}{c}\text { Oleacein } \\
(3,4-\mathrm{DHPEA}-\mathrm{EDA})\end{array}$ & $8.01 \mathrm{a}$ & $2.50 \mathrm{~b}$ & $2.30 \mathrm{a}$ & $25.16 \mathrm{~b}$ & $\mathrm{nf}$ \\
\hline & $\begin{array}{c}\text { Oleocanthal } \\
\text { (p-HPEA-EDA) }\end{array}$ & $2.07 \mathrm{~b}$ & $3.54 \mathrm{c}$ & $1.13 \mathrm{~b}$ & $4.20 \mathrm{a}$ & $\mathrm{nf}$ \\
\hline & $\begin{array}{c}\text { Oleuropein aglycon } \\
\text { (3,4-DHPEA-EA) }\end{array}$ & $49.65 \mathrm{a}$ & $7.28 \mathrm{a}$ & $13.71 \mathrm{a}$ & $62.67 \mathrm{a}$ & $0.13 \mathrm{a}$ \\
\hline & $\begin{array}{c}\text { Deacetoxy-10-hydroxy } \\
\text { oleuropein aglycon } \\
\text { (DAc-10-OH Ole Agly); }\end{array}$ & $0.61 \mathrm{a}$ & $0.18 \mathrm{a}$ & $\mathrm{nf}$ & $0.84 \mathrm{~b}$ & $\mathrm{nf}$ \\
\hline & Elenolic acid & $16.88 \mathrm{~b}$ & $3.70 \mathrm{~b}$ & $1.72 \mathrm{a}$ & $3.18 \mathrm{~b}$ & $\mathrm{nf}$ \\
\hline & $\begin{array}{l}\text { Ligstroside aglycon } \\
\text { (p-HPEA-EA) }\end{array}$ & $\mathrm{nf}$ & $8.09 \mathrm{c}$ & $3.46 \mathrm{c}$ & $12.86 \mathrm{a}$ & $0.22 \mathrm{a}$ \\
\hline Flavonoids & Luteolin & $0.83 \mathrm{~b}$ & $0.54 \mathrm{a}$ & $0.51 \mathrm{~b}$ & $0.41 \mathrm{a}$ & $0.14 \mathrm{~b}$ \\
\hline
\end{tabular}

The results are given by the mean value $(n=3)$ of independent determinations, including extraction and injection. Different letters for each phenolic compound indicate statistical differences at $p<0.05$. nf $=$ not found.

Monovarietal oil samples showed a very similar phenolic composition. Differences from a quantitative point of view were recorded, in particular for the portion of the secoiridoids where 
3,4-DHPEA-EA (oleuropein aglycon) was the main compound found. With regard to flavonoid derivatives, luteolin was detected in all samples, contrary to diosmetin and apigenin-7-glucoside.

The main phenolic compound was 3,4-DHPEA-EA (oleuropein aglycon) with contents varying from $62.67 \mathrm{mg} \mathrm{kg}^{-1}$ to $0.13 \mathrm{mg} \mathrm{kg}^{-1}$, together with p-HPEA-EA (ligstroside aglycon) that ranged from $12.86 \mathrm{mg} \mathrm{kg}^{-1}$ to $0.22 \mathrm{mg} \mathrm{kg}^{-1}$; 3,4-DHPEA-EDA (oleacein) was found in a range of $2.30 \mathrm{mg} \mathrm{kg}^{-1}$ to $25.16 \mathrm{mg} \mathrm{kg}^{-1}$; p-HPEA-EDA (oleocanthal) showed the highest content $\left(3.54 \mathrm{mg} \mathrm{kg}^{-1}\right)$ in Chemlal and the lowest content $\left(2.07 \mathrm{mg} \mathrm{kg}^{-1}\right)$ in Tefahi.

In the group of phenolic acids, the amounts of the compounds were less abundant in olive oils than the amount of the secoiridoids group. $p$-coumaric acid, caffeic acid, ferulic acid, vanillic acid, and $p$-hydroxybenzoic acid were the phenolic acids found in some of the oils with small amounts.

\subsection{Antioxidant Activity and Total Content of Phenolic Compounds}

The results of the in vitro antioxidant assays performed on the olive oil phenolic fraction extracts are summarized in Table 5. They revealed that the oil PFE issued from the Tefahi cultivar was the most active, while Zebboudj was the least active and did not give any result in 3/5 of the assays (DPPH, FRAP, and TEAC). There was no significant difference observed between the oil PFE of Tefahi and Manzanilla cultivars in the results obtained with FRAP, TEAC, and BCB assays and much closer results were observed in the Folin-Ciocalteu test between the oils of Manzanilla, Chemlal, and Gelb Elfarroudj.

Table 5. Antioxidant activity and total phenolic content of the olive oil phenolic fraction extracts as measured by means of five in vitro assays.

\begin{tabular}{|c|c|c|c|c|c|}
\hline Varieties & $\begin{array}{c}\text { Folin-Ciocalteu } \\
\mu \mathrm{g} \mathrm{GAEmg} \mathrm{G}^{-1} \\
( \pm \mathrm{SD})\end{array}$ & $\begin{array}{c}\text { DPPH } \\
\text { mmol TEmg-1 } \\
( \pm \text { SD })\end{array}$ & $\begin{array}{c}\text { FRAP } \\
\text { mmol } \\
\mathrm{Fe}^{2+} \mathrm{Emg}^{-1} \\
( \pm \mathrm{SD})\end{array}$ & $\begin{array}{c}\text { TEAC } \\
\text { mM TEmg }^{-1} \\
( \pm \text { SD })\end{array}$ & $\begin{array}{c}\text { BCB } \\
\mathrm{IC}_{50 \% \mathrm{mgml}^{-1}} \\
\text { (CL95) }\end{array}$ \\
\hline Tefahi & $237.19 \pm 23.70$ & $0.70 \pm 0.08$ & $0.84 \pm 0.12$ & $0.31 \pm 0.07$ & $1.84(1.52-2.15)$ \\
\hline Chemlal & $59.24 \pm 8.99 * *$ & $0.05 \pm 0.001^{* *}$ & $0.12 \pm 0.02^{* *}$ & $0.008 \pm 0.001^{* *}$ & $14.81(12.74-17.21)^{*}$ \\
\hline Gelb Elfarroudj & $48.94 \pm 5.65^{* *}$ & $0.03 \pm 0.004^{* *}$ & $0.044 \pm 0.002^{*}$ & $0.020 \pm 0.003 * *$ & $8.46(7.41-9.66)^{*}$ \\
\hline Manzanilla & $46.32 \pm 9.10^{* *}$ & $0.22 \pm 0.06^{* *}$ & $0.34 \pm 0.20$ & $0.37 \pm 0.02$ & $6.54(5.36-7.99)$ \\
\hline Zebboudj & $37.34 \pm 4.71 * *$ & - & - & - & $7.44(5.62-9.84)$ \\
\hline
\end{tabular}

Results are expressed as mean \pm SD of three experiments for DPPH, FRAP, and TEAC tests, and as $50 \%$ mean inhibition concentration $\left(\mathrm{IC}_{50}\right)$ with confidence limits $(\mathrm{CL})$ at $95 \%$ for the $\mathrm{BCB}$ assay. GAE: Gallic acid equivalents; TE: Trolox equivalents. ${ }^{*} p<0.05 ;{ }^{* *} p<0.01$ versus Tefahi oil phenolic fraction extract.

\section{Discussion}

The qualitative parameters of the studied oils highlight very high values which bring into question their quality. In particular, Zebboudj, Manzanilla, and Gelb Elfarroudj oils had high values of free acidity (0.75-1.25 g of oleic acid $100 \mathrm{~g}^{-1}$ of oil), which could be connected with the prolonged ripening before the olive harvest.

The amount of phenolic compounds in EVOO is an important factor when evaluating its quality, given that the natural phenols improve its resistance to oxidation, and to a certain extent, are responsible for its sharp bitter taste.

In this study, for the first time, the composition of secoiridoids in olive oils of some Algerian cultivars was analyzed with UHPLC-HESI-MS. The most abundant secoiridoids of the olive oil analyzed were the aglycones of oleuropein and ligstroside, and these results agree with previous data found for Algerian Chemlal olive oils [30,31]. In general, all the samples showed lower concentrations of oleocanthal, if compared to the other cultivars of the countries of the Mediterranean basin $[19,20]$.

We suggest that the composition in phenolic compounds of the oils under study could be higher if the harvesting time is done earlier; previous studies demonstrated that olives have the highest phenolic compound content at the phase between green and darker skin $[13,32]$. The extraction of olive oil from black olive fruits was justified by the Algerian producers in that it allows them to get better olive oil yield [33]. 
The phenolic compounds are known to contribute to antioxidant/radical scavenging activity; their concentrations have a relationship with the percentage of radical inhibition [34]. Consequently, the lack of antioxidant activity in some experiments when testing Zebboudj oil PFE could be explained by the low concentration of phenolic compounds. However, Zebboudj oil PFE demonstrated good BCB results, probably due to the presence of vanillic acid, since previous studies reported its antioxidant and protective effects on the peroxidation of lipids [35].

The antioxidant activity of Tefahi oil PFE may be related to its composition in secoiridoids mainly due to oleuropein aglycon (3,4-DHPEA-EA) and elenolic acid. The antioxidant activity of Manzanilla oil PFE is probably due to the presence also of high amounts of secoiridoids, mostly oleuropein aglycon (3,4-DHPEA-EA) and ligstroside aglycon (p-HPEA-EA). We noticed that in both Tefahi and Manzanilla, there were high amounts of oleuropein aglycon (3,4-DHPEA-EA), a hydrophilic secoiridoid that demonstrated in other works a metal-chelation and a free-radical-scavenging action [36]. Some other phenolics may contribute to the antioxidant activity with their remarkable presence such as the phenolic acid oleacein (3,4-DHPEA-EDA) in both Tefahi and Manzanilla oil PFE.

In another study about the Manzanilla cultivar growing in Australia, the authors reported amounts of caffeic acid $\left(0.46 \mathrm{mg} \mathrm{kg}^{-1}\right)$ less than the amounts found in this study $\left(0.8 \mathrm{mg} \mathrm{kg}^{-1}\right)$, whereas they detected other compounds that we could not find such as vanillic and ferulic acids. The same study reported that a significant gradual decrease was noted in major polyphenolic compounds in the later harvest stage [37].

Other authors tested the antioxidant activity of Algerian olive oils (cultivar Chemlal and Olea europaea L. subsp. Oleaster) extracted using laboratory technics instead of extraction in the mill, and the results of antioxidant activity were higher with respect to our results [30,38]. Unfortunately, there are no studies on the composition and antioxidant activity of olive oils from Algerian cultivars growing in the same region of our study (Setif and Batna); for this reason, it is difficult to compare the results. Certainly the region of cultivation of the various cultivars plays a decisive role in the chemical characteristics of the oils produced [39].

The technics used in the commercial mills for the extraction of olive oil may play also a crucial role in the olive oil quality such as the malaxation temperature. In literature it was reported that a significant increment of total phenols concentration was found with a maximum at $27^{\circ} \mathrm{C}$, whereas for higher temperatures $\left(30-36{ }^{\circ} \mathrm{C}\right)$, a progressive decrement was observed [40]. The malaxation temperature used in the commercial mill in this study was $30^{\circ} \mathrm{C}$; we suggest that reducing this temperature may give better olive oil quality.

In our study, the olive oils were obtained with the method used from local producers in Algeria. This method did not give us a very high olive oil quality. In general, to produce EVOOs with high quality which reinforces its enhancement in the international market, a better knowledge of the local cultivars and the best agronomic techniques are necessary.

\section{Conclusions}

Antioxidant activity as well as fatty acids composition, phenolic acids, and secoiridoids content of some Algerian monovarietal olive oils were investigated. The results indicate that the quality parameters are acceptable for all oils, except for Zebboudj oil. The most important results from the chemical point of view were the phenolic portion. Manzanilla reported the greatest quantity of secoiridoids in particular as regards oleuropein aglycon, ligstroside aglycon, and oleacein $(62.67 \mathrm{mg}$ $\mathrm{kg}^{-1}, 12.86 \mathrm{mg} \mathrm{kg}^{-1}$, and $25.16 \mathrm{mg} \mathrm{kg}^{-1}$, respectively). Tefahi oil showed quality parameters in line with international regulations, an appreciable content of monounsaturated fatty acids $(66.93 \%)$ but modest levels of oleuropein aglycon $\left(49.65 \mathrm{mg} \mathrm{kg}^{-1}\right)$ and other secoiridoids if compared to those of other oils of the Mediterranean areas. The antioxidant activity of Tefahi oil was found to be the best among the cultivars used. This study constitutes a starting point for the diffusion and marketing of Tefahi monovarietal oils due to their phenolic content and antioxidant capacity. 
This is just a preliminary report since only a single sample from each cultivar was investigated. However, a more in-depth study must be done on agronomic techniques and ripening stage before the olive harvest takes place, which has been shown to have great influence on the quality of the oils produced.

Author Contributions: Conceptualization, V.D.S. and M.G.M.; methodology, V.D.S. and S.B.; software, M.C.; validation, V.D.S., S.B., C.M., and M.C.; formal analysis, V.D.S., S.B., C.M., and M.C.; investigation, V.D.S., S.B., C.M., and M.C.; resources, V.D.S. and M.C.; data curation, M.C., V.D.S., C.M., and S.B.; writing-original draft preparation, S.B., V.D.S., and M.C.; writing-review and editing, M.G.M. and V.D.S.; visualization, S.B.; supervision, V.D.S. and M.C.; project administration, M.G.M.; funding acquisition, M.G.M. All authors have read and agreed to the published version of the manuscript.

Funding: This work has been partially supported by National Research Council, CNR—DISBA project NutrAge (project nr.7022).

Acknowledgments: The authors are grateful to Loucif Ayache, an investor in agriculture, owner of the modern mill and of some of the cultivars. He provided olive oil samples and allowed the inquiry at the mill. The authors thank Dott.ssa Lucia Sollima for her administrative support.

Conflicts of Interest: The authors declare that there is no conflict of interest.

\section{References}

1. Gomez Caravaca, A.M.; Maggio, R.M.; Cerretani, L. Chemometric applications to assess quality and critical parameters of virgin and extra-virgin olive oil. Anal. Chim. Acta 2016, 913, 1-21. [CrossRef]

2. Ouni, Y.; Taamalli, A.; Maria Gómez-Caravaca, A.; Segura-Carretero, A.; Fernández-Gutiérrez, A.; Zarrouk, M. Characterisation and quantification of phenolic compounds of extra-virgin olive oils according to their geographical origin by a rapid and resolutive LC-ESI-TOF MS method. Food Chem. 2011, 127, 1263-1267. [CrossRef]

3. Deng, J.; Xu, Z.; Xiang, C.; Liu, J.; Zhou, L.; Li, T.; Yang, Z;; Ding, C. Comparative evaluation of maceration and ultrasonic-assisted extraction of phenolic compounds from fresh olives. Ultrason. Sonochem. 2017, 37, 328-334. [CrossRef]

4. Genovese, A.; Yang, N.; Linforth, R.; Sacchi, R.; Fisk, I. The role of phenolic compounds on olive oil aroma release. Food Res. Int. 2018, 112, 319-327. [CrossRef]

5. Ghanbari, R.; Anwar, F.; Alkharfy, K.M.; Gilani, A.H.; Saari, N. Valuable Nutrients and Functional Bioactives in Different Parts of Olive (Olea europaea L.). Int. J. Mol. Sci. 2012, 13, 3291-3340. [CrossRef]

6. Reboredo-Rodríguez, P.; Varela-López, A.; Forbes-Hernández, T.Y.; Gasparrini, M.; Afrin, S.; Cianciosi, D.; Zhang, J.; Pia Manna, P.; Bompadre, S.; Quiles, J.L.; et al. Phenolic Compounds Isolated from Olive Oil as Nutraceutical Tools for the Prevention and Management of Cancer and Cardiovascular Diseases. J. Funct. Foods 2018, 19, 2305. [CrossRef]

7. García-Rodríguez, R.; Belaj, A.; Romero-Segura, C.; Sanz, C.; Pérez, A.G. Exploration of genetic resources to improve the functional quality of virgin olive oil. J. Funct. Foods 2017, 38, 1-8. [CrossRef]

8. Oueslati, I.; Krichene, D.; Manaï, H.; Taamalli, W.; Zarrouk, M.; Flamini, G. Monitoring the volatile and hydrophilic bioactive compounds status of fresh and oxidized Chemlali. Food Res. Int. 2018, 112, 425-433. [CrossRef]

9. Jiménez, B.; Sánchez-Ortiz, A.; Lorenzo, M.L.; Rivas, A. Influence of fruit ripening on agronomic parameters, quality indices, sensory attributes and phenolic compounds of Picudo olive oils. Food Res. Int. 2013, 54, 1860-1867. [CrossRef]

10. Ammar, S.; Kelebek, H.; Zribi, A.; Abichou, M.; Selli, S.; Bouaziz, M. LC-DAD/ESI-MS/MS characterization of phenolic constituents in Tunisian extra-virgin olive oils: Effect of olive leaves addition on chemical composition. Food Res. Int. 2017, 100, 477-485. [CrossRef]

11. Natasa, P.K.; Reza, A.; Nikolaos, S.T. Application of an advanced and wide scope non-target screening workflow with LC-ESI-QTOF-MS and chemometrics for the classification of the Greek olive oil varieties. Food Chem. 2018, 256, 53-61.

12. Salvo, A.; Rotondo, A.; La Torre, G.L.; Cicero, N.; Dugo, G. Determination of 1,2/1,3-diglycerides in Sicilian extra-virgin olive oils by ${ }^{1} \mathrm{H}-\mathrm{NMR}$ over a one-year storage period. Nat. Prod. Res. 2017, 31, 822-828. [CrossRef] 
13. Bakhouche, A.; Lozano Sánchez, J.; Bengana, M.; Fernández Gutiérrez, A.; Segura Carretero, A. Time course of Algerian Azeradj extra virgin olive oil quality during olive ripening. Eur. J. Lipid Sci. Technol. 2015, 117, 389-397. [CrossRef]

14. Yakhlef, W.; Arhab, R.; Romero, C.; Brenes, M.; de Castro, A.; Medina, E. Phenolic composition and antimicrobial activity of Algerian olive products and by-products. LWT Food Sci. Technol. 2018, 93, 323-328. [CrossRef]

15. Abdul-Hussain, K.H.; Abdul-Hussain, M.S. Influence of the gibberelic acid on the germination of the seeds of olive-tree Olea europaea L. J. Cent. Eur. Agric. 2004, 5, 1-4.

16. International conventions and agreements-laws and decrees, judgments, decisions, notices, communications and announcements. Off. J. People's Democr. Repub. Alger. 2008, 5, 46.

17. Algerian Ministry of Agriculture. Fixation des Conditions D'éligibilité au Soutien sur le Compte D'affectation Spéciale no.302-139 Intitulé "Fonds National de Développement Agricole" ligne 1 "Développement de L'investissement Agricole", Ainsi que les Modalités de Paiement des Subventions; Decision no. 414; 2014. Available online: https://eur-lex.europa.eu/legal-content/EN/ALL/?uri=CELEX:32016R2095 (accessed on 22 October 2020).

18. European Commission. Regulation no. 2016/2095 amending regulation no. 2568/91 on the characteristics of olive oil and olive-residue oil and on the relevant methods of analysis. Available online: https: //eur-lex.europa.eu/legal-content/EN/ALL/?uri=CELEX:32016R2095 (accessed on 1 December 2016).

19. Di Stefano, V.; Melilli, M.G. Effect of storage on quality parameters and phenolic content of Italian extra-virgin olive oils. Nat. Prod. Res. 2020, 34, 78-86. [CrossRef]

20. Grilo, F.; Novara, M.E.; D'Oca, M.C.; Rubino, S.; Lo Bianco, R.; Di Stefano, V. Quality evaluation of extra-virgin olive oils from Sicilian genotypes grown in a high-density system. Int. J. Food Sci. Nutr. 2020, 71, 397-409. [CrossRef]

21. Di Stefano, V.; Avellone, G.; Bongiorno, D.; Indelicato, S.; Massenti, R.; Lo Bianco, R. Quantitative evaluation of the phenolic profile in fruits of six avocado (Persea americana) cultivars by ultra-high-performance liquid chromatography-heated electrospray-mass spectrometry. Int. J. Food Prop. 2017, 6, 1-27. [CrossRef]

22. Napoli, E.; Siracusa, L.; Ruberto, G.; Carrubba, A.; Lazzara, S.; Speciale, A.; Cimino, F.; Saija, A.; Cristani, M. Phytochemical profiles, phototoxic and antioxidant properties of eleven Hypericum species. A comparative study. Phytochemistry. 2018, 152, 162-173. [CrossRef]

23. Ouerghemmi, S.; Sebei, H.; Siracusa, L.; Ruberto, G.; Saija, A.; Cimino, F.; Cristani, M. Comparative study of phenolic composition and antioxidant activity of leaf extracts from three wild Rosa species grown in different Tunisia regions: Rosa canina L., Rosa moschata Herrm. And Rosa sempervirens L. Ind. Crops Prod. 2016, 94, 167-177. [CrossRef]

24. Dehimi, K.; Speciale, A.; Saija, A.; Dahamna, S.; Raciti, R.; Cimino, F.; Cristani, M. Antioxidant and anti-inflammatory properties of Algerian Thymelaeamicrophylla Coss. And Dur. extracts. Pharmacogn. Mag. 2016, 12, 203-210.

25. Boussahel, S.; Speciale, A.; Dahamna, S.; Amar, Y.; Bonaccorsi, I.; Cacciola, F.; Cimino, F.; Donato, P.; Ferlazzo, G.; Harzallah, D.; et al. Flavonoid profile, antioxidant and cytotoxic activity of different extracts from Algerian Rhamnus alaternus L. bark. Pharmacogn. Mag. 2015, 11, 102-109.

26. Martorana, M.; Arcoraci, T.; Rizza, L.; Cristani, M.; Bonina, F.P.; Saija, A.; Trombetta, D.; Tomaino, A. In vitro antioxidant and in vivo photoprotective effect of pistachio (Pistacia vera L. variety Bronte) seed and skin extracts. Fitoterapia 2013, 85, 41-48. [CrossRef]

27. International Olive Council. Trade Standard Applying to Olive Oils and Olive Pomace Oils COI/T.15/NC no. 3/Rev 13. Available online: https://www.internationaloliveoil.org/wp-content/uploads/2019/11/COI-T.15-NC. -No-3-Rev.-13-2019-Eng.pdf (accessed on 23 October 2020).

28. Boudour Benrachou, N.; Plard, J.; Pinatel, C.; Artaud, J.; Dupuy, N. Fatty Acid Compositions of Olive Oils from Six Cultivars from East and South-Western Algeria. Adv. Food Technol. Nutri. Sci. 2017, 3, 1-5. [CrossRef]

29. Laincer, F.; Iaccarino, N.; Amato, J.; Pagano, B.; Pagano, A.; Tenore, G.; Tamendjari, A.; Rovellini, P.; Venturini, S.; Bellan, G.; et al. Characterization of monovarietal extra virgin olive oils from the province of Béjaïa (Algeria). Food Res. Int. 2016, 89, 1123-1133. [CrossRef]

30. Laincer, F.; Laribi, R.; Tamendjari, A.; Arrar, L.; Rovellini, P.; Venturini, S. Olive oils from Algeria: Phenolic compounds, antioxidant and antibacterial activities. Grasas Aceites 2014, 65, 1-10. 
31. Louadj, L.; Giuffre, A.M. Analytical characteristics of olive oil produced with three different processes in Algeria. Riv. Ital. Sostanze Grasse. 2010, 87, 186-195.

32. Bengana, M.; Bakhouche, A.; Lozano Sánchez, J.; Amir, Y.; Youyou, A.; Segura Carretero, A.; Fernández Gutiérrez, A. Influence of olive ripeness on chemical properties and phenolic composition of "Chemlal" extra-virgin olive oil. Food Res. Int. 2013, 54, 1868-1875. [CrossRef]

33. Yangui, A.; Costa-Font, M.; Gil, J.M. The effect of personality traits on consumers' preferences for extra virgin olive oil. Food Qual Prefer. 2016, 51, 27-38. [CrossRef]

34. McDonald, S.; Prenzler, P.D.; Antolovich, M.; Robards, K. Phenolic content and antioxidant activity of olive extracts. Food Chem. 2001, 73, 73-84. [CrossRef]

35. Chou, T.H.; Ding, H.Y.; Hung, W.J.; Liang, C.H. Antioxidative characteristics and inhibition of $\alpha$-melanocyte-stimulating hormone-stimulated melanogenesis of vanillin and vanillic acid from Origanumvulgare. Exp. Dermatol. 2010, 19, 742-750. [CrossRef] [PubMed]

36. Visioli, F.; Poli, A.; Galli, C. Antioxidant and Other Biological Activities of Phenols from Olives and Olive Oil. Med. Res. Rev. 2002, 22, 65-75. [CrossRef] [PubMed]

37. Alowaiesh, B.; Singha, Z.; Fangc, Z.; Kailisd, S.G. Harvest time impacts the fatty acid compositions, phenolic compounds and sensory attributes of Frantoio and Manzanilla olive oil. Sci. Hortic. 2018, 234, 74-80. [CrossRef]

38. Bouarroudja, K.; Tamendjaria, A.; Larbat, R. Quality, composition and antioxidant activity of Algerian wild olive (OleaeuropaeaL. subsp.Oleaster) oil. Ind. Crop. Prod. 2016, 83, 484-491. [CrossRef]

39. Mailer, R.J.; Ayton, J.; Graham, K. The Influence of Growing Region, Cultivar and Harvest Timing on the Diversity of Australian Olive Oil. J. Am. Oil Chem. Soc. 2010, 87, 877-884. [CrossRef]

40. Parenti, A.; Spugnoli, P.; Masella, P.; Calamai, L. The effect of malaxation temperature on the virgin olive oil phenolic profile under laboratory-scale conditions. Eur. J. Lipid Sci. Technol. 2008, 110, 735-741. [CrossRef]

Publisher's Note: MDPI stays neutral with regard to jurisdictional claims in published maps and institutional affiliations. 